\title{
Determination of Heavy Metal Concentration in Cultivated Vegetables - A Case Study of Mysore District
}

\author{
Shobha M S ${ }^{1}$ and Shiva Kumar D*2 \\ ${ }^{1}$ Department of Microbiology, Maharani's Science College for Women, Mysuru-570 005, Karnataka \\ ${ }^{2}$ Department of Studies in Environmental Science, University of Mysore, Manasagangothri, Mysuru-570 006,
} Karnataka

\begin{abstract}
Our surrounding is filled up with a large number of toxicants in different forms and different composition. These toxicants mat contaminate our water, land and atmosphere where we live. Heavy metal pollution in the environment is a significant issue and problem and has its negative impact on the whole living system including in the agriculture fields. But the heavy metals are also the natural constituents of the environment, but indiscriminate use for human purposes has altered their geochemical cycles and biochemical balance. The more and more quantity of heavy metals may results in toxification in natural resources like the soil and aquatic environments. In this context, the present paper reviews about the quantity of heavy metals accumulated in vegetables and amount of heavymetals present in soil of agricultural fields of selected taluks of Mysuru district.
\end{abstract}

Keywords: Mysuru, Toxicity, Heavy metals, Geochemical cycle, Agriculture.

\section{Introduction}

Most of the heavy metals are exist naturally at low concentrations in soils, rocks, water, and biota, sufficient to provide living systems with essential nutrients but at levels too low to cause toxicity. Since the industrial revolution, heavy metals have become a seriously pervasive pollutant in environment, through industrial effluents and landfill leaching, mining activities, fertilizer and pesticide use in agriculture, the burning of waste and fossil fuels, and municipal waste treatment (Diels et al., 2006). Once these heavy metals have been released into the environment, they cannot be degraded and will accumulate in the environment persistently, including the food chain. Exposure to heavy metals through uptake of drinking water or foods can lead to their accumulation in plants, animals and humans (Mulligan et al., 2001). But now the conventional heavy metals contaminated wastewater or soil treatments, such as chemical precipitation or ion exchange and adsorption are not effective or uneconomical (Kapoor and Viraraghavan, 1995; Matheickal et al., 1997; Cheung and Gu, 2007).

Microbial processes that bind metals and form minerals are widespread and represent a fundamental part of key biogeochemical cycles (Cheung et al., 2006; DeJong et al., 2006; Stanislav and Tomas, 2006; Cheung and Gu, 2007; Han and Gu, 2010; Veronica et al., 2012). Carbonate precipitation is an important aspect of biomineralization, and has been investigated extensively due to its wide range of technological implications.

Some of the heavy metals act as micronutrients for the growth of animals and human beings when present in trace quantities, whereas others such as $\mathrm{Cd}$, As, and $\mathrm{Cr}$ act as carcinogens (Feig et al., 1994; Trichopoulos, 1997). The contamination of vegetables with heavy metals due to soil and atmospheric contamination poses a threat to its quality and safety. Dietary intake of heavy metals also poses risk to animals and human health. Heavy metals such as $\mathrm{Cd}$ and $\mathrm{Pb}$ have been shown to have carcinogenic effects (Trichopoulos, 1997). High concentrations of heavy metals $(\mathrm{Cu}, \mathrm{Cd}$ and $\mathrm{Pb})$ in fruits and vegetables were related to high prevalence of upper gastrointestinal cancer (Turkdogan et al., 2002).

\section{Materials And Methods}

Vegetable samples were collected and samples were classified as fruits, green vegetables, leafy vegetables and general (tubers, bulbs, bean and rice), according to CEAGESP. In each group, only the most commonly traded vegetables in 2008 were collected, comprising 223 samples of 83 plant species. Samples were identified and packed into polyethylene bags. In the laboratory, they were washed following the same procedures as for food preparation to remove any surface deposits (Chary et al., 2008). Then, the vegetables were rewashed with deionized water and separated into edible and non-edible parts. The edible parts were airdried at $65^{\circ} \mathrm{C}$, weighed and finely ground in a Willey mill.

Acid digestion and metals determination of samples Tri-acid mixture $(15 \mathrm{ml}, 70 \%$ high purity HNO3, $65 \% \mathrm{HClO} 4$ and $70 \% \mathrm{H} 2 \mathrm{SO} 4 ; 5: 1: 1$ ) was added to the beaker containing $1 \mathrm{~g}$ dry vegetable sample (Allen et al., 1986). The mixture was then digested at 80 _C till the transparent solution was achieved. After cooling, the digested samples were filtered using What man No. 42 filter paper and the filtrate was diluted to $50 \mathrm{ml}$ with deionised water and were determined by atomic absorption spectro photometry (Varian-SpectrAA 140). 


\section{Soil sampling:}

- Divide the study area into sampling points so that each sample represents an area of not more than 6 acres.

- Fix sampling spots to represent the study area.

- Scrape away the surface litter, stones etc. and collect samples in to a bucket from each spot up to the required depth by making a ' $\mathrm{V}$ ' shaped cut by using a spade. Take a slice of soil from both the sides. Collect the same quantity from each of sampling spots. Place the sample on a plastic sheet and mix by discarding stones, roots etc. and take out the required quantity of soil in to polythene bag by adapting quartering technique.

Table 1: Soil Sampling Stations

\begin{tabular}{|l|l|l|l|}
\hline Serial No & Station code & Name of the Taluk & Village \\
\hline 1 & $\mathrm{P} 1$ & KR NAGAR & Mirle \\
\hline 2 & $\mathrm{P} 2$ & HUNASUR & Hirikyathanahalli \\
\hline 3 & $\mathrm{P} 3$ & PERIYAPATNA & Chittena halli \\
\hline 4 & $\mathrm{P} 4$ & NANANAGUD & Doora \\
\hline 5 & $\mathrm{P} 5$ & HD KOTE & H M Halli \\
\hline
\end{tabular}

\section{Results And Discussion}

The results of the present studies were summarized in Table 2. The concentrations of the heavy metals was estimated thorough ICP-MS for the $\mathrm{Cd}, \mathrm{Ni}, \mathrm{Pb}, \mathrm{Cu}$ and $\mathrm{Cr}$. The concentrations of heavy metals was estimated by crushing the whole plant body including root and compared with the corresponding permissible limits established by National Agency for Sanitary Vigilance (Anvisa) (1965). According to Anvisa, the permissible limits for $\mathrm{Cd}, \mathrm{Ni}, \mathrm{Pb}$ and $\mathrm{Cr}$ are 1.0, 5.0, 0.5 and $0.1 \mathrm{mg} \mathrm{kg}-1$, respectively (fresh weight), with no recommendation for Co.

The daily intake of $\mathrm{Cd}$ was estimated as $0.008 \mathrm{mg}$, which represents approximately $10.7 \%$ of the $\mathrm{RfD}$, established to $0.001 \mathrm{mg} \mathrm{kg}-1$ of body weight per day, equivalent to $0.07 \mathrm{mg}$ per day for a $70 \mathrm{~kg}$ adult (WHO, 1993). The daily intake was lower than the tolerable daily intake (TDI). In the present study the concentration ranged from $0.06 \mathrm{mg} / \mathrm{kg}$ to $0.31 \mathrm{mg} / \mathrm{kg}$

$\mathrm{Cr}$ is an important element for the insulin activity and DNA transcription. However an intake below $0.02 \mathrm{mg}$ per day could reduce cellular responses to insulin (Kohlmeier, 2003). The daily intake, estimated as $0.016 \mathrm{mg}$, was lower than the RfD established at $1.5 \mathrm{mg} \mathrm{kg}-1$ per day (equivalent to $105 \mathrm{mg}$ per day) (US EPA, 2010). This value was also lower than that recommended by the US National Council (NRC, 1989) for Cr3+: from 0.05 to $0.2 \mathrm{mg}$.). In the present study the concentration of $\mathrm{Cr}$ ranged from $0.06 \mathrm{mg} / \mathrm{kg}$ to $1.2 \mathrm{mg} / \mathrm{kg}$

$\mathrm{Ni}$ content in the adult human body should remain below $0.1 \mathrm{mg}$ per day, and excess may cause damages to DNA and cell structures (Kohlmeier, 2003). The daily intake of Ni was estimated as $0.046 \mathrm{mg}$, which represents approximately $3.3 \%$ of RfD established in $0.02 \mathrm{mg} \mathrm{kg}-1$ per day, equivalent to $1.4 \mathrm{mg}$ per day for a $70 \mathrm{~kg}$ adult (WHO, 1993). The present research measures about $0.08 \mathrm{mg} / \mathrm{kg}$ to $0.81 \mathrm{mg} / \mathrm{kg}$.

Copper can be found in many kinds of food, in drinking water and in air. Because of that we absorb eminent quantities of copper each day by eating, drinking and breathing. The absorption of copper is necessary, because copper is a trace element that is essential for human health. Although humans can handle proportionally large concentrations of copper, too much copper can still cause eminent health problems. In the present study the copper was estimated about $0.17 \mathrm{mg} / \mathrm{kg}$ to $1.2 \mathrm{mg} / \mathrm{kg}$.

The Leafy vegetables tend to accumulate high amounts of $\mathrm{Cd}, \mathrm{Ni}$, and $\mathrm{Pb}$ due not only to their large leaf area and high transpiration rate, but also to the fast growth rate of these plants as observed by Itanna (2002). However, concentrations of $\mathrm{Pb}$, that exceeded the established permissible limit of $0.5 \mathrm{mg} \mathrm{kg}-1$, were not observed for a specific class of vegetables in this study.

Table 2 - Concentrations of heavy metals in selected vegetables of Mysuru district.

\begin{tabular}{|l|l|l|l|l|l|l|}
\hline Vegetables & Scientific Name & $\mathbf{C d}$ & $\mathbf{N i}$ & $\mathbf{P b}$ & $\mathbf{C u}$ & $\mathbf{C r}$ \\
\hline Purple Cabbage & Brassica oleracea L & 0.06 & 0.28 & 1.26 & 0.68 & 0.51 \\
\hline Rocket & Eruca sativa L. & 0.1 & 0.37 & 0.81 & 0.4 & 0.4 \\
\hline Cauliflower & Brassica oleracea var botrytis & 0.09 & 0.2 & 0.47 & 0.38 & 0.21 \\
\hline Crisphead Lettuce & Lactuca sativa L. & 0.18 & 0.41 & 0.32 & 0.42 & 0.38 \\
\hline Smooth Lettuce & Lactuca sativa L. & 0.12 & 0.24 & 0.52 & 0.18 & 0.16 \\
\hline Coriander & Coriandrum sativum L. & 0.24 & 0.7 & 1.1 & 0.62 & 0.17 \\
\hline Cabbage & Brassica oleracea var. acephala D.C. & 0.28 & 0.68 & 1.4 & 1.2 & 1.2 \\
\hline Endive & Cichorium endivia L. & 0.12 & 0.48 & 0.78 & 0.28 & 0.31 \\
\hline Chard & Beta vulgaris L. var. cicla & 0.09 & 0.18 & 0.8 & 0.17 & 0.16 \\
\hline Watercress & Nasturtium officinale sp. & 0.1 & 0.42 & 0.76 & 0.62 & 0.5 \\
\hline Sweet corn & Zea Mays L. & 0.08 & 0.08 & 0.41 & 0.62 & 0.27 \\
\hline Spinach & Tetragonia expansa & 0.15 & 0.41 & 1.34 & 0.78 & 0.35 \\
\hline Broccoli & Brassica oleracea L & 0.09 & 0.31 & 1.2 & 0.48 & 0.72 \\
\hline
\end{tabular}


Determination Of Heavy Metal Concentration In Cultivated Vegetables - A Case Study Of Mysore

\begin{tabular}{|l|l|l|l|l|l|l|}
\hline Celery & Apium graveolens L. & 0.09 & 0.29 & 1.1 & 0.41 & 0.28 \\
\hline Parsley & Petroselinum crispum (Mill.) Nym. & 0.31 & 0.81 & 1.3 & 0.71 & 0.3 \\
\hline White Cabbage & Brassica oleracea L. var. capitata & 0.08 & 0.19 & 0.87 & 0.41 & 0.2 \\
\hline Iceberg Lettuce & Lactuca sativa L. & 0.08 & 0.19 & 0.34 & 0.18 & 0.38 \\
\hline
\end{tabular}

Although the HQ-based risk assessment method does not provide a quantitative estimate for the probability of an exposed population experiencing a reverse health effect, it indeed provides an indication of the risk level due to exposure to pollutants (Chary et al., 2008). Many researchers consider the risk estimation method reliable (Chary et al., 2008; Khan et al., 2008; Wang et al., 2005) and it has been proven to be valid and useful. However, this HQ method considers only exposure to HMs via consumption of vegetables, without taking into account other vias like dermal contact, soil ingestion, and other factors such as the presence of agrochemicals and herbicide molecules.

Table 3: Values of Hazard Quotients (HQ) and Hazard Index (HI).

\begin{tabular}{|l|l|l|l|l|l|l|}
\hline Population & $\mathrm{Cd}$ & $\mathrm{Ni}$ & $\mathrm{Pb}$ & $\mathrm{Co}$ & $\mathrm{Cr}$ & $\mathrm{HI}$ \\
\hline Adults & 0.107 & 0.033 & 0.417 & 0.013 & 0.00015 & 0.57 \\
\hline Children & 0.130 & 0.039 & 0.499 & 0.016 & 0.00018 & 0.68 \\
\hline
\end{tabular}

When the hazard index exceeds 1.0, there is concern for potential health effects (Huang et al., 2008). Even though there was no apparent risk when each metal was analyzed individually, the potential risk could be multiplied when considering all HMs. HI for adults and children were 0.57 and 0.68 , respectively (Table 6). Although HI was higher for children, neither population suffered from ingestion of vegetables contaminated with HMs.

\section{Conclusion}

Heavy metal contamination of vegetables cannot be underestimated as these foodstuffs are important components of human diet. Vegetables are rich sources of vitamins, minerals, and fibers, and also have beneficial antioxidative effects. However, intake of heavy metal-contaminated vegetables may pose a risk to the human health. Heavy metal contamination of the food items is one of the most important aspects of food quality assurance. The uptake of heavy metals in vegetables are influenced by some factors such as climate, atmospheric depositions, the concentrations of heavy metals in soil, the nature of soil on which the vegetables are grown and the degree of maturity of the plants at the time of harvest The obtained results declared that concentrations of major studied metals were exceeding than the recommended maximum acceptable levels proposed by the Joint FAO/WHO Expert Committee on Food Additives.

\section{References}

[1]. Baird, C. 2002. Environmental Chemistry. Bookman, Porto Alegre, RS, Brazil (in Portuguese).

[2]. Biego, G.H.; Joyeux, M.; Hartemann, P.; Debry, G. 1998. Daily intake of essential minerals and metallic micropollutants from foods in France. Science of the Total Environment 217: 27-36.

[3]. Chary, N.S.; Kamala, C.T.; Raj, D.S.S. 2008. Assessing risk of heavy metals from consuming food grown on sewage irrigated soils and food chain transfer. Ecotoxicology and Environmental Safety 69: 513-24.

[4]. Cheung, K.H., Gu, J.D., 2007. Mechanisms of hexavalent chromium detoxification by bacteria and bioremediation applications. International Biodeterioration \& Biodegradation 59, $8 \mathrm{e} 15$

[5]. Cheung, K.H., Lai, H.Y., Gu, J.-D., 2006. Membrane-associated hexavalent chromium reductase of Bacillus megaterium TKW 3 with induced expression. Journal of Microbiology and Biotechnology 16, 855e862.

[6]. Codex Alimentarius Commission. 1995. Codex general standard for contaminants and toxins in food and feed. Available at: http://www.codexalimentarius.net/download/standards/17/CXS_193e.pdf [Accessed Mar. 10, 2010].

[7]. DeJong, J.T., Fritzges, M.B., Nusslein, K., 2006. Microbially induced cementation to control sand response to undrained shear. Journal of Geotechnical and Geoenvironmental Engineering 132, 1381e1392.

[8]. Ferré-Huguet, N.; Marti-Cid, R.; Schuhmacher, M.; Domingo, J.L. 2008. Risk assessment of metals from consuming vegetables, fruits and rice grown on soils irrigated with waters of the Ebro River in Catalonia, Spain. Biological Trace Element Research 123: 66-79.

[9]. Food and Nutrition Board. 2004. Dietary Reference Intakes [DRIs]: Recommended Intakes for Individuals. National Academy of Sciences, Washington, DC, USA.

[10]. Fujita, Y., Ferris, E.G., Lawson, R.D., Colwell, F.S., Smith, R.W., 2000. Calcium carbonate precipitation by ureolytic subsurface bacteria. Geomicrobiology Journal 17, 305e318.

[11]. Fujita, Y., Redden, G.D., Ingram, J.C., Cortez, M.M., Ferris, F.G., Smith, R.W., 2004. Strontium incorporation into calcite generated by bacterial ureolysis. Geochimica et Cosmochimica Acta 68, $3261 \mathrm{e} 3270$.

[12]. Han, X., Gu, J.-D., 2010. Sorption and transformation of toxic metals by microorganisms. In: Mitchell, R., Gu, J.-D. (Eds.), Environmental Microbiology, second ed. John Wiley, New York, pp. 153e176.

[13]. Huang, M.L.; Zhou, S.L.; Sun, B.; Zhao, Q.G. 2008. Heavy metals in wheat grain: Assessment of potential health risk for inhabitants in Kunshan, China. Science of the Total Environment 405: 54-61.

[14]. Itanna, F. 2002. Metals in leafy vegetables grown in Addis Ababa and toxicological implications. Ethiopian Journal of Health Development 6: 295-302.

[15]. Ivanov, V., Chu, J., 2008. Applications of microorganisms to geotechnical engineering for bioclogging and biocementation of soil in situ. Reviews in Environmental Science and Biotechnology 7, 139e153 
[16]. Kapoor, A., Viraraghavan, T., 1995. Fungal biosorption e an alternative treatment option for heavy metal bearing wastewaters: a review. Bioresource Technology 53, 195e206.

[17]. Khan, S.; Cao, Q.; Zheng, Y.M.; Huang, Y.Z.; Zhu, Y.G. 2008. Health risks of heavy metals in contaminated soils and food crops irrigated with wastewater in Beijing, China. Environmental Pollution 152: 686-692.

[18]. Kohlmeier, M. 2003. Nutrient Metabolism. Elsevier, San Diego, CA, USA.

[19]. Le Metayer-Levrel, G., Castanier, S., Orial, G., Loubiere, J.F., Perthuisot, J.P., 1999. Applications of bacterial carbonatogenesis to the protection and regeneration of limestones in buildings and historic patrimony. Sedimentary Geology 126, $25 \mathrm{e} 34$.

[20]. Luo, K., Cui, Y.H., Wang, X.M., He, Y.H., Wu, Y.L., 2001. A study on formation and purification and enzymological properties of Terrabacter tumescens urease ant its application. Journal of Gansu Sciences 13, 54e58.

[21]. Matheickal, J.T., Yu, Q., Feltham, J., 1997. Cu (II) binding by E-radiata biomaterial. Environmental Technology 18, $25 \mathrm{e} 34$.

[22]. Miyazawa, M.; Pavan, M.A.; Muraoka, T.; Carmo, C.A.F.S.; Melo, W.J. 2009. Chemical Analysis of Plant Tissues. p. 191-233. In: Silva, F.C., ed. Manual of chemical analysis of soils, plants and fertilizers. Embrapa Informação Tecnológica, Brasília, DF, Brazil (in Portuguese).

[23]. Mulligan, C.N., Yong, R.N., Gibbs, B.F., 2001. Remediation technologies for metal-contaminated soils and groundwater: an evaluation. Engineering Geology 60, $193 \mathrm{e} 207$.

[24]. Murphy, E.M., Ginn, T.R., 2000. Modeling microbial processes in porous media. Hydrogeology Journal 8, $142 \mathrm{e} 158$.

[25]. National Agency for Sanitary Vigilance [Anvisa]. 1965. Decree $\mathrm{n}^{\circ}$ 55.871. Available at: http://www.anvisa.gov.br/legis/decretos/55871_65.htm [Accessed Mar. 16, 2010]. (in Portuguese).

[26]. National Research Council [NRC]. 1989. Recommended Dietary Allowances. National Academy Press, Washington, DC, USA

[27]. Oliver, M.A. 1997. Soil and human health: a review. European Journal of Soil Science 48: 573-592.

[28]. R.; Rauta, C.; Carstea, S.; Ghelase, I. 1996. Soil-plant-man relationships in heavy metal polluted areas in Romania. Applied Geochemistry 11: 105-107.

[29]. Santos, E.E.; Lauria, D.C.; Porto da Silveira, C.L. 2004. Assessment of daily intake of trace elements due to consumption of foodstuffs by adult inhabitants of Rio de Janeiro city. Science of the Total Environment 327: 69-79.

[30]. Stanislav, V., Tomas, R.K., 2006. Biosorption of $\mathrm{Cd} 2 \mathrm{p}$ and $\mathrm{Zn} 2 \mathrm{p}$ by cell surface-engineered Saccharomyces cerevisiae. International Biodeterioration \& Biodegradation 60, 96e102.

[31]. Tripathi, R.M.; Raghunath, R.; Krishnamoorthy, T.M. 1997. Dietary intake of heavy metals in Bombay city, India. Science of the Total Environment 208: 149-159.

[32]. van Paassen, L.A., Whiffin, V.S., Harkes, M.P., 2007. Microbial carbonate precipitation as a soil improvement technique. Geomicrobiology Journal 24, 417e423.

[33]. Veronica, L.C., Liliana, B.V., Carlos, M.A., 2012. Indigenous microorganisms as potential bioremediators for environments contaminated with heavy metals. International Biodeterioration \& Biodegradation 69, 28e37.

[34]. Volpe, M.G.; La Cara, F.; Volpe, F.; De Mattia, A.; Serino, V.; Pettito, F.; Zavalloni, C.; Limone, F.; Pellecchia, R.; De Prisco, P.P.; Di Stasio, M. 2009. Heavy metal uptake in the enological food chain. Food Chemistry 117: 553-560.

[35]. Wagner, G.J. 1993. Accumulation of cadmium in crop plants and its consequences to human health. Advances in Agronomy 51: $173-212$.

[36]. Wang, X.L.; Sato, T.; Xing, B.S.; Tao, S. 2005. Health risks of heavy metals to the general public in Tianjin, China via consumption of vegetables and fish. Science of the Total Environment 350: 28-37.

[37]. Warren, L.A., Maurice, P.A., Parmar, N., Ferris, F.G., 2001. Microbially mediated calcium carbonate precipitation: Implications for interpreting calcite precipitation and for solid-phase capture of inorganic contaminants. Geomicrobiology Journal 18, 93e115.

[38]. World Health Organization [WHO]. 1993. Evaluation of Certain Food Additives and Contaminants. In: Forty-First Report of the Joint FAO/WHO Expert Committee on Food Additives., WHO, Geneva, Switzerland. (WHO Technical Series, 837).

[39]. World Health Organization [WHO]. 2004. Evaluation of certain food additives and Contaminants. In: Sixty-First Report of the Joint FAO/WHO Expert Committee on Food Additives.

\section{Graphical representation of the heavy metals accumulated in selected plant species of Mysuru district}

\section{Cadmium}

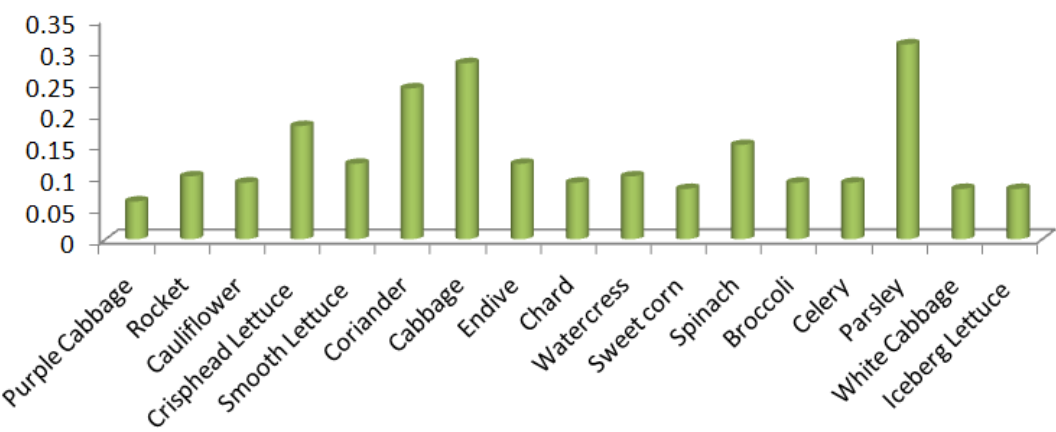



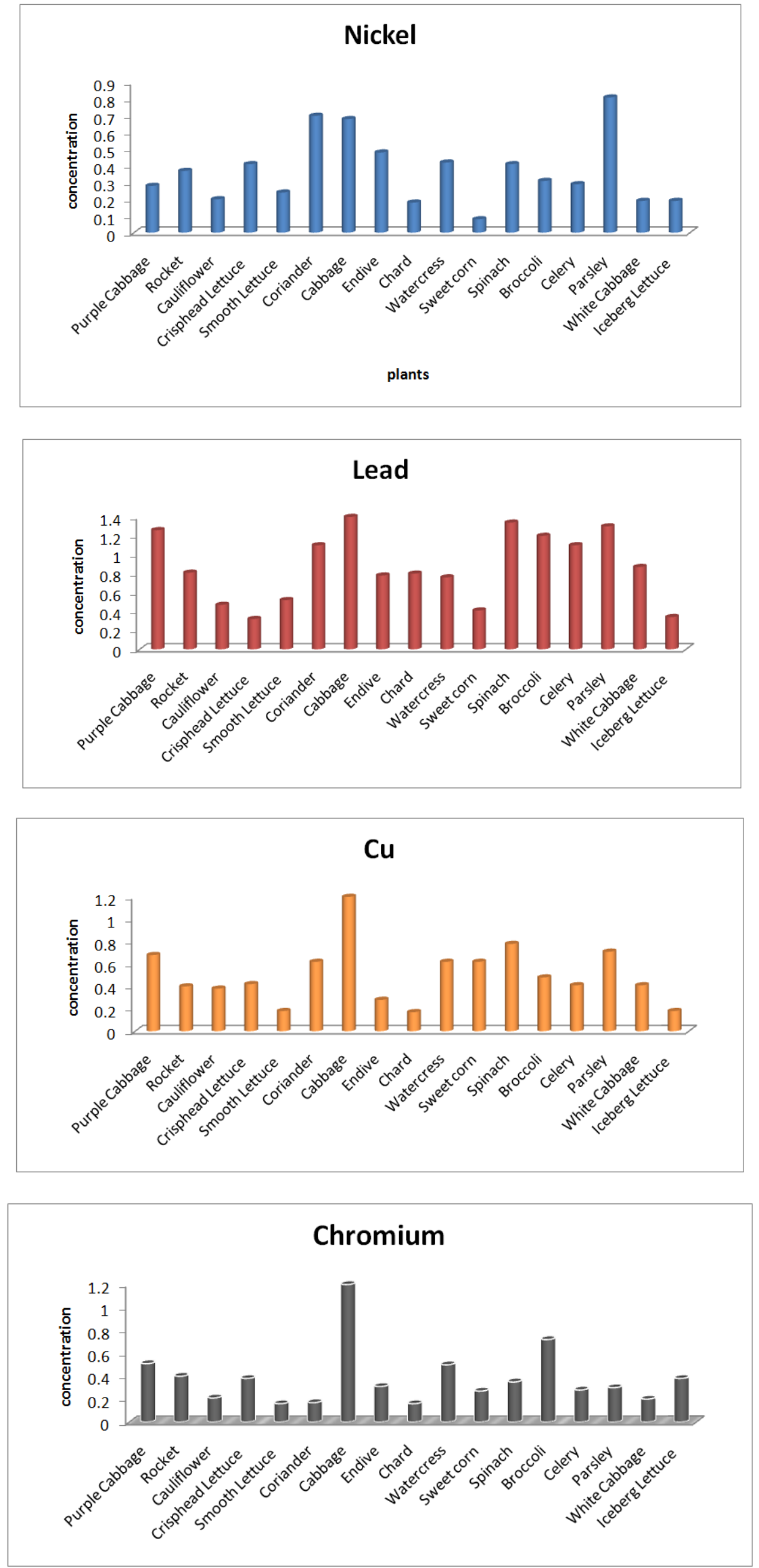